\title{
Conductance Properties of the Acetylcholine Receptor Current of Guinea Pig Outer Hair Cells
}

\author{
Pascal Darbon $^{1,2}$, Daniel J. Wright ${ }^{1}$, and Michael G. Evans ${ }^{1}$ \\ ${ }^{1}$ School of Life Sciences, Keele University, Keele, Staffordshire ST5 5BG, UK \\ ${ }^{2}$ Present address: Département Nociception et Douleur, INCI UPR 3212 CNRS-Université de Strasbourg, 21 Rue René Descartes, \\ 61084 Strasbourg Cedex, France
}

Received: 2 April 2010; Accepted: 27 September 2010; Online publication: 13 October 2010

\begin{abstract}
The nicotinic acetylcholine receptor (AChR) current of outer hair cells (OHCs) was investigated in isolated and voltage-clamped cells under conditions where coactivating $\mathrm{Ca}^{2+}$-activated $\mathrm{K}^{+}$currents had been abolished using internal BAPTA, external calcium removal and/or depolarisation to positive voltages. The AChR current activated rapidly and thereafter declined in the continued presence of ACh. Reversal potential measurements indicated that it was a non-specific cation current with a substantial $\mathrm{Ca}^{2+}$ permeability. It had a characteristic bidirectional rectification with an especially prominent outward component in solutions containing $1 \mathrm{mM} \mathrm{Ca}^{2+}$. The $I-V$ relation was fitted with a single-energy barrier model. The fit suggests a blocking site within the channel, situated about one third of the way through the membrane from the outside and probably normally occupied by $\mathrm{Ca}^{2+}$ or $\mathrm{Mg}^{2+}$. The AChR current was sensitive to the external $\mathrm{Ca}^{2+}$ since it was reduced, to differing extents, in nominally $\mathrm{Ca}^{2+}$-free saline or in high $\mathrm{Ca}^{2+}$ saline $(10 \mathrm{mM})$. In the presence of a nominally $\mathrm{Mg}^{2+}$-free solution containing $0.4 \mathrm{mM} \mathrm{Ca}{ }^{2+}$, the currents were larger, indicating a potentiated response. This type of behaviour is also shown by recombinant $\alpha 9 \alpha 10$ AChRs, suggesting a close similarity. The AChR current at both positive and negative voltages was reduced in external solutions where most of the $\mathrm{Na}^{+}$ had been replaced by $\mathrm{NMG}^{+}$. The conductance
\end{abstract}

Correspondence to: Michael G. Evans · School of Life Sciences · Keele University · Keele, Staffordshire ST5 5BG, UK. Telephone: +44-1782733594; email: m.g.evans@cns.keele.ac.uk properties of the OHC AChR are compared with $\alpha 9 \alpha 10$ receptors and nicotinic receptors in other hair cells and discussed in terms of the accepted functional role of providing calcium influx leading to efferent synaptic inhibition of hair cells.

Keywords: cochlea, outer hair cell, acetylcholine, acetylcholine receptor, nicotinic receptor, patch clamp, whole cell recording

\section{INTRODUCTION}

The outer hair cells (OHCs) of the mammalian cochlea play a central role in hearing, actively amplifying the vibrations of the basilar membrane on a cycle-by-cycle basis and thereby providing enhanced sensitivity and sharp tuning. The basis of the amplification is thought to be somatic electromotility, provided by prestin, a motor protein that is packed into the OHC lateral membrane (Zheng et al. 2000; Liberman et al. 2002). There might also be a contribution made by the ciliary bundle, which can itself generate force (Kennedy et al. 2005). Although the relative importance of these mechanisms in amplifying sounds is presently unclear, both are fast voltage-driven processes and thus would be expected to be modulated by the OHC efferent synaptic input from the olivocochlear bundle. In cats and guinea pigs, electrical stimulation of the olivocochlear bundle produces raised thresholds of both inner hair cells (IHCs) and auditory nerve fibres (Wiederhold and Kiang 1970; Brown and Nuttall 1984). The effect is largest at the characteristic frequency where sensitivity is reduced by a factor of about 10 in mammals and up to 25 
in turtles (Art et al. 1984). Thus, the olivocochlear bundle can exert a powerful effect on cochlear sensitivity.

The efferent nerve fibres to the OHCs are cholinergic and single axons contact several OHCs. The hair cell acetylcholine receptor (AChR) appears to have similar properties across different vertebrate species and functions as a cation channel with a high Ca permeability (see Fuchs and Murrow 1992; Blanchet et al. 1996; Gomez-Casati et al. 2005). On application of ACh, the AChRs open, allowing calcium and other cations to flow into the cell, leading to the activation of a $\mathrm{Ca}^{2+}$ dependent $\mathrm{K}^{+}$current. Fast $\mathrm{Ca}^{2+}$ imaging of OHCs has shown that the $\mathrm{Ca}^{2+}$ rise occurs initially at the base of the cell and that $\mathrm{Ca}^{2+}$-induced $\mathrm{Ca}^{2+}$ release from intracellular stores contributes to the $\mathrm{Ca}^{2+}$ rise (Evans et al. 2000). The $\mathrm{Ca}^{2+}$-dependent $\mathrm{K}^{+}$channels are of the SK type (SK2: Dulon et al. 1998; Yuhas and Fuchs 1999). Since the activation of the SK current depends on the opening of AChRs, a fast application of ACh to a hair cell voltage clamped close to its resting potential produces a biphasic response, with a small inward AChR current followed by a larger outward $\mathrm{K}^{+}$ current (Fuchs and Murrow 1992; Evans 1996; Blanchet et al. 1996). Thus, the $\mathrm{K}^{+}$(SK2) current transforms synaptic excitation into inhibition.

Recently, considerable progress has been made in our understanding of the molecular composition of the hair cell AChR. Expression of $\alpha 9$ and $\alpha 10$ subunits of the AChR receptor family in Xenopus oocytes leads to heteromeric $\alpha 9 \alpha 10 \mathrm{AChRs}$ with properties similar to the native hair cell AChR (Elgoyhen et al. 2001). These subunits have been shown to be present in cochlear hair cells and are therefore likely to be present in, or indeed to constitute, the native AChR. The homomeric $\alpha 9$ AChR also has some similarity to the native AChR; however, the $\alpha 9 \alpha 10$ AChR more closely resembles the hair cell AChR in terms of its electrical properties (in particular rectification and desensitisation) and bellshaped sensitivity to external Ca (Elgoyhen et al. 2001; Weisstaub et al. 2002). Both recombinant receptors show similar sensitivity to agonists and antagonists (such as $\alpha$-bungarotoxin and strychnine) and thus cannot easily be distinguished pharmacologically. Currents flowing through both of these recombinant receptors reverse at about $-10 \mathrm{mV}$, in line with their relative lack of specificity for small monovalent cations.

Because of the experimental difficulties associated with maintaining mature cochlear hair cells in good physiological condition in vitro, most of the data pertinent to the molecular classification of the hair cell AChR in terms of its constituent subunits have been obtained either from non-mammalian hair cells (e.g. McNiven et al. 1996) or from neonatal rat IHCs (Glowatzki and Fuchs 2000; Gomez-Casati et al. 2005). Rat IHCs receive a transient efferent innervation for approximately the second postnatal week, during which time the animals start hearing (about postnatal day 12). The aim of this paper was to characterise the ionic conductance of the OHC AChR in order to assess its degree of similarity with both the recombinant AChRs ( $\alpha 9$ and $\alpha 9 \alpha 10)$ and AChRs already characterised in other hair cells, thereby providing a better basis for its eventual classification.

\section{METHODS}

The isolation of outer hair cells from young adult guinea pigs (250-500 g) was as previously described (Evans 1996). A brief version follows. Animals were humanely killed by rapid cervical dislocation in accordance with UK Home Office regulations and the bullae removed. The bulla was opened to expose the cochlea and then immersed in physiological saline (normal external solution) at room temperature. The organ of Corti (excluding the apical turn) was peeled away from the modiolus using a hyperdermic needle and exposed to collagenase $(0.5 \mathrm{mg} / \mathrm{ml})$ for about $10 \mathrm{~min}$. The cells were mechanically dissociated by twice sucking the entire suspension into a Gilson pipette and then transferred to the experimental chamber (volume about $200 \mu \mathrm{l}$ ) that had been pretreated with conconavalin A $(2 \mathrm{mg} / \mathrm{ml})$ to facilitate cell adhesion. Isolated OHCs were typically 50$65 \mu \mathrm{m}$ in length, consistent with an original location in turns 2-3. The chamber was superfused with external solution at a rate of $0.1-1.0 \mathrm{ml} / \mathrm{min}$, although the upper half of this range was preferred for experiments requiring a change of solution. Solutions were selected by switching a small solenoid valve.

\section{Electrophysiology}

Recording pipettes were pulled from thin-walled glass (GC120TF-10, Clark Electromedical Instruments) and had a resistance of 3-4 M $\Omega$. The pipette shank was coated with ski wax (Toko AG, Altstatten, Switzerland) to reduce pipette capacitance. In whole cell recording mode, series resistance compensation $(60-70 \%)$ was applied and periodically checked throughout the recording. ACh $(100 \mu \mathrm{M})$ dissolved in an external solution was applied by pressure ejection from a patch pipette (tip diameter about $2-4 \mu \mathrm{m}$ ) or a doublebarrelled pipette, positioned 5-15 $\mu \mathrm{m}$ from the base of the cell. Pressure was controlled using a pneumatic picopump (PV 820, World Precision Instruments, FL, USA) and, in the case of the double-barrelled pipette, applied to one or other barrel via a solenoid valve. The double-barrelled pipette was pulled from theta glass (TGC200-10, Clark Electromedical Instruments). This pressure 
application method has onset and offset time constants of about 40 and $80 \mathrm{~ms}$, respectively (Evans 1996). During analysis of the data, voltages were corrected for the uncompensated series resistance and for the junction potential between the pipette filling solution and the bath, which varied between -6 and $0 \mathrm{mV}$ depending on the filling solution. Pipette current (filtered at $0.9-3.0 \mathrm{kHz}$ ) and voltage were digitised and stored on disk. Experiments were run using Signal software with a 1401-plus interface (Cambridge Electronic Design, Cambridge, UK).

\section{Solutions}

Two sets of external solutions were used in this study. The first was based on minimal essential medium (MEM) and was used with the $\mathrm{K}^{+}$-based internal solutions. The other was a simplified version of that used in an earlier study (Evans 1996) and was used with $\mathrm{Cs}^{+}$-based internal solutions. The "MEM" solution contained $(\mathrm{mM}): \mathrm{NaCl}$, 128; KCl, 5.4; $\mathrm{MgCl}_{2}, 0.5 ; \mathrm{MgSO}_{4}, 0.4 ; \mathrm{CaCl}_{2}, 1.26$; $\mathrm{Na}_{2} \mathrm{HPO}_{4}, 0.34 ; \mathrm{KH}_{2} \mathrm{PO}_{4}, 0.44$; HEPES, 25; glucose, 6 ( $\mathrm{pH} 7.4)$. For all solutions, $\mathrm{pH}$ was adjusted with $\mathrm{NaOH}$ unless otherwise indicated. In the nominally $\mathrm{Ca}^{2+}$-free solution, $\mathrm{CaCl}_{2}$ was omitted and $\mathrm{NaCl}$ was increased to $130 \mathrm{mM}$. In the low $\mathrm{Ca}^{2+}$ solution, $\mathrm{Ca}^{2+}$ was $0.4 \mathrm{mM}$ and $\mathrm{Mg}^{2+}$ salts were omitted. The $\mathrm{K}^{+}$based intracellular solution contained $(\mathrm{mM}): \mathrm{KCl}$, 130; $\mathrm{MgCl}_{2}, 4 ; \mathrm{Na}_{2} \mathrm{ATP}$, 2; EGTA, 5 (or 5 BAPTA); HEPES, 5, pH 7.3 ( $\mathrm{KOH}$ or $\mathrm{CsOH})$. The simplified external solution contained $(\mathrm{mM})$ : $\mathrm{NaCl}, 142 ; \mathrm{KCl}$, 4; $\mathrm{CaCl}_{2}, 1 ; \mathrm{MgCl}_{2}, 1.5$; glucose, 16; HEPES 5 ( $\mathrm{pH}$ 7.4). Usually, $\mathrm{CsCl}(0.5-4 \mathrm{mM})$ was added to this external solution in place of an equivalent concentration of $\mathrm{NaCl}$ to reduce or block $I_{\mathrm{Kn}}$, a prominent voltage-dependent $\mathrm{K}^{+}$current in OHCs (Housley and Ashmore 1992). The $\mathrm{Cs}^{+}$-based internal solution contained $(\mathrm{mM})$ : $\mathrm{CsCl}, 133 ; \mathrm{KCl}, 4$; $\mathrm{MgCl}_{2}, 4 ; \mathrm{CaCl}_{2}, 0.5 ; \mathrm{Na}_{2} \mathrm{ATP}, 2 ; \mathrm{NaOH}, 23 ; \mathrm{CsOH}$, 23; glucose, 8; BAPTA 10; HEPES 5 ( $\mathrm{pH} 7.3$ ). For the $5 \mathrm{mM}$ BAPTA version of this solution, $\mathrm{CsCl}$ was $140 \mathrm{mM}$ and $\mathrm{pH}$ was adjusted with $\mathrm{NaOH}$ $(\sim 25 \mathrm{mM})$. In solutions where $\mathrm{CaCl}_{2}$ was increased, $\mathrm{NaCl}$ was reduced $\left(1.4 \mathrm{mM} \mathrm{Na}^{+}\right.$equivalent to $1 \mathrm{mM}$ $\left.\mathrm{Ca}^{2+}\right)$. In experiments requiring a low concentration of external $\mathrm{Na}^{+}$or internal $\mathrm{Cs}^{+}, N$-methyl-D-glucamine $\left(\mathrm{C}_{7} \mathrm{H}_{17} \mathrm{~N}^{+} \mathrm{O}_{5}\left(\mathrm{NMG}^{+}\right)\right)$was the replacement cation. The internal $\mathrm{NMG}^{+}$solution contained $(\mathrm{mM}): \mathrm{NMGCl}, 125 ; \mathrm{KCl}, 4 ; \mathrm{MgCl}_{2}, 4 ; \mathrm{CaCl}_{2}, 1$; $\mathrm{Na}_{2}$ ATP, 2; BAPTA, 10; HEPES, 5 (pH 7.3, adjusted with $\mathrm{CsOH}, \sim 50 \mathrm{mM})$. The external $\mathrm{NMG}^{+}$solution contained $(\mathrm{mM}): \mathrm{NaCl}, 30, \mathrm{NMGCl}, 111 ; \mathrm{KCl}, 4$; CsCl, $1 ; \mathrm{MgCl}_{2}, 1.5 ; \mathrm{CaCl}_{2}, 1$; HEPES, 5 (pH 7.4). For experiments requiring low internal $\mathrm{Cl}$, methanesulphonate was the replacement anion. The low internal $\mathrm{Cl}^{-}$solution contained $(\mathrm{mM})$ : $\mathrm{CsCl}, 20$; $\mathrm{CsSO}_{3} \mathrm{CH}_{3}, 105 ; \mathrm{KCl}, 4 ; \mathrm{MgCl}_{2}, 4 ; \mathrm{CaCl}_{2}, 1 ; \mathrm{Na}_{2} \mathrm{ATP}$, 2; BAPTA, 10; HEPES, 5 ( $\mathrm{pH} 7.3$, adjusted with $\mathrm{CsOH}, \sim 55 \mathrm{mM})$. Cesium methane sulphonate $\left(\mathrm{CsSO}_{3} \mathrm{CH}_{3}\right)$ was made by neutralising methanesulphonic acid (Fluka) with CsOH. NMGCl was made by neutralising $N$-methyl-D-glucamine with HCl. Chemicals were obtained from Sigma unless stated otherwise.

In experiments requiring the application of ACh in a test (non-control) solution (e.g. nominally $\mathrm{Ca}^{2+}$-free solution in Fig. 1), we first flowed the test solution through the bath for a few minutes and then applied ACh dissolved in the test solution via a doublebarrelled puffer pipette (allowing comparison with a control ACh application via the other barrel). Occasionally, a single-barrelled puffer pipette was used, requiring a change of puffer pipette so that ACh could be applied in the appropriate test solution. An exception to this occurred with $\alpha$-bungarotoxin, a nicotinic antagonist that washes off relatively slowly in OHCs and was applied in the bath only (see Evans 1996).

\section{Analysis}

Currents were measured using Signal software (CED). Voltages were corrected for the uncompensated series resistance and junction potential before plotting of $I-$ $V$ curves. In order to assess the time-dependent components of the AChR currents, a sigmoidal function was used (Chan and Evans 1998):

$$
I(t)=k\left(1-\exp \left(-(t-d) / \tau_{1}\right)\right)^{2}\left(\exp \left(-(t-d) / \tau_{2}\right)\right)
$$

with $k$ the proportionality constant, $d$ the delay; $\tau_{1}$ the activation time constant and $\tau_{2}$ the deactivation time constant. $I-V$ curves were fitted with a single-energy barrier function (Jack et al. 1975):

$$
I(V)=k\left(\exp \left((1-\gamma)\left(V-V_{\mathrm{r}}\right) / V_{\mathrm{s}}\right)-\exp \left(-\gamma\left(V-V_{\mathrm{r}}\right) / V_{\mathrm{s}}\right)\right)
$$

with $k$ the proportionality constant, $\gamma$ the electrical distance through the membrane electrical field of an energy barrier, expressed as a proportional distance from the outside, $V_{\mathrm{r}}$ the reversal potential and $V_{\mathrm{s}}$ a measure of the steepness of the rectification. The fits were done using Fig. P software (Biosoft, Cambridge). Values of $V_{\mathrm{r}}$ were then used to estimate the permeability of the AChR channel to $\mathrm{Ca}^{2+}$ relative to small monovalent cations using the constant field equation. We assumed equal permeability of the major small monovalent cations $\left(\mathrm{K}^{+}, \mathrm{Cs}^{+}, \mathrm{Na}^{+}\right)$and neglected the contribution of $\mathrm{Mg}^{2+}$. The reversal potential $\left(V_{\mathrm{r}}\right)$ 
of the AChR current is given by (see Mayer and Westbrook 1987):

$$
V_{\mathrm{r}}=R T / F \ln \left[\left(-b+\left(b^{2}-4 a c\right)^{\frac{1}{2}}\right) / 2 a\right]
$$

in which:

$$
\begin{aligned}
a= & {\left[\mathrm{K}^{+}\right]_{\mathrm{i}}+P_{\mathrm{Na}} / P_{\mathrm{K}}\left(\left[\mathrm{Na}^{+}\right]_{\mathrm{i}}\right)+P_{\mathrm{Cs}} / P_{\mathrm{K}}\left(\left[\mathrm{Cs}^{+}\right]_{\mathrm{i}}\right) } \\
& +P_{\mathrm{NMG}} / P_{\mathrm{K}}\left(\left[\mathrm{NMG}^{+}\right]_{\mathrm{i}}\right)+4\left(P_{\mathrm{Ca}} / P_{\mathrm{Cs}}\right) \\
& \times\left(\left[\mathrm{Ca}^{2+}\right]_{\mathrm{i}}\right)
\end{aligned}
$$

$$
\begin{aligned}
b= & \left(\left[\mathrm{K}^{+}\right]_{\mathrm{i}}-\left[\mathrm{K}^{+}\right]_{\mathrm{o}}\right)+\left(P_{\mathrm{Na}} / P_{\mathrm{K}}\right)\left(\left[\mathrm{Na}^{+}\right]_{\mathrm{i}}-\left[\mathrm{Na}^{+}\right]_{\mathrm{o}}\right) \\
& +P_{\mathrm{Cs}} / P_{\mathrm{K}}\left(\left[\mathrm{Cs}^{+}\right]_{\mathrm{i}}-\left[\mathrm{Cs}^{+}\right]_{\mathrm{o}}\right) \\
& +P_{\mathrm{NMG}} / P_{\mathrm{K}}\left(\left[\mathrm{NMG}^{+}\right]_{\mathrm{i}}-\left[\mathrm{NMG}^{+}\right]_{\mathrm{o}}\right) \\
c= & -\left[\mathrm{K}^{+}\right]_{\mathrm{o}}-\left(P_{\mathrm{Na}} / P_{\mathrm{K}}\right)\left[\mathrm{Na}^{+}\right]_{\mathrm{o}}-P_{\mathrm{Cs}} / P_{\mathrm{K}}\left(\left[\mathrm{Cs}^{+}\right]_{\mathrm{O}}\right) \\
& -P_{\mathrm{NMG}} / P_{\mathrm{K}}\left(\left[\mathrm{NMG}^{+}\right]_{\mathrm{o}}\right) \\
& -4\left(P_{\mathrm{Ca}} / P_{\mathrm{Cs}}\right)\left[\mathrm{Ca}^{2+}\right]_{\mathrm{o}}
\end{aligned}
$$

In the above equations, $F, R$ and $T$ have their usual thermodynamic meanings, $P_{\mathrm{K}}, P_{\mathrm{Na}}, P_{\mathrm{Cs}}, P_{\mathrm{NMG}}$ and $P_{\mathrm{Ca}}$ are the membrane permeabilities to $\mathrm{K}^{+}, \mathrm{Na}^{+}, \mathrm{Cs}^{+}$, $\mathrm{NMG}^{+}$and $\mathrm{Ca}^{2+}$ respectively, and $\mathrm{i}$ and $\mathrm{o}$ refer respectively to the intracellular and the extracellular concentration of an ion (set to zero if the ion was not present). We further assumed that $\left[\mathrm{Ca}^{2+}\right]_{\mathrm{i}}$ was $1 \mu \mathrm{M}$, which although higher than would be expected based on the composition of the internal solutions was chosen since the intracellular $\mathrm{Ca}^{2+}$ would be expected to be raised by $\mathrm{Ca}^{2+}$ influx (for example through the AChR). In this study, grouped data are expressed as means $\pm \mathrm{SE}$ of the mean ( $n=$ number of cells). Differences between experimental groups were assessed using Student's $t$ test assuming equal variance between the two samples, with $p<0.05$ being considered as significant.

\section{RESULTS}

In order to study the OHC AChR current in isolation, it was essential to block the opposing and larger $\mathrm{K}^{+}$ current flowing through SK2 channels. Three approaches were used in this study: (1) removal of external $\mathrm{Ca}^{2+}$ (greatly limiting $\mathrm{Ca}^{2+}$ influx through the AChR), (2) clamping the cell to positive voltages (where SK2 current was essentially zero due to its pronounced voltage dependence (see Evans 1996)) and (3) using high internal concentrations of the fast
$\mathrm{Ca}^{2+}$ buffer (BAPTA, $5-10 \mathrm{mM}$ ) to minimise the rise in intracellular $\mathrm{Ca}^{2+}$ produced by ACh. In addition, a number of experiments were performed with a $\mathrm{Cs}^{+}-$ based internal solution since this reduced the background whole cell conductance which was advantageous given the small size of the AChR current. Much of the initial characterisation of the AChR current was done using the $\mathrm{Cs}^{+}$-based internal solution containing $10 \mathrm{mM}$ BAPTA. Manipulations involving the lowering of external $\mathrm{Ca}^{2+}$ were mainly done with the $\mathrm{K}^{+}$-based internal solutions, the conditions of choice for the longer recordings involving one or two bath changes.

\section{Isolation of the $\mathrm{AChR}$ current by $\mathrm{Ca}^{2+}$ removal}

For these experiments, we used the $\mathrm{K}^{+}$-based internal solution containing $5 \mathrm{mM}$ EGTA as a $\mathrm{Ca}^{2+}$ buffer. From a holding potential of about $-60 \mathrm{mV}$, voltage steps induced maintained currents in the relatively short OHCs that were used in this study (Fig. 1A). These cells would be expected to have come from the second and third cochlear turns (see "Methods"). The ACh-evoked current (in response to the application of $100 \mu \mathrm{M} \mathrm{ACh}$ ), which was made up of the AChR current and the larger SK2 current, riding on top of the maintained "background" current, exhibited the following characteristic signs: a reversal potential at $-65 \mathrm{mV}$ (about $20 \mathrm{mV}$ positive to the calculated $\mathrm{K}^{+}$ equilibrium potential), a peak at $-20 \mathrm{mV}$ and an $\mathrm{N}-$ shaped $I-V$ relation (Fig. 1A, C). The $\mathrm{N}$ shape is characteristic of $\mathrm{Ca}^{2+}$-activated $\mathrm{K}^{+}$currents dependent on $\mathrm{Ca}^{2+}$ influx, in this case through the AChR (Evans 1996). Removal of external $\mathrm{Ca}^{2+}$ (nominally $\mathrm{Ca}^{2+}-$ free) did not greatly affect the background (voltagedependent) current, but it did eliminate the SK2

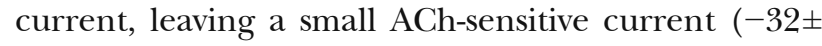
$11 \mathrm{pA}$ at $-60 \mathrm{mV}, n=4)$. This current (AChR current) reversed at $-15 \mathrm{mV}$ and showed inward rectification negative to $-40 \mathrm{mV}$ and outward rectification at positive voltages (Fig. 1A, C). This bidirectional rectification, usually with an especially prominent outward component, has been found in all hair cells where AChR currents have been studied in isolation in the presence of strong $\mathrm{Ca}^{2+}$ buffering from internal BAPTA (e.g. Fuchs and Murrow 1992; Dulon and Lenoir 1996; Blanchet et al. 1996; Gomez-Casati et al. $2005)$, and it is a characteristic feature of the $\alpha 9 \alpha 10$ recombinant receptor (Weisstaub et al. 2002).

The current flowing through the recombinant $\alpha 9 \alpha 10$ receptor, and also the AChR from neonatal IHCs, has a distinctive "biphasic" dependence on external $\mathrm{Ca}^{2+}$ arising from two separate processes, one a voltageindependent potentiation and the other a voltagedependent block (Weisstaub et al. 2002; Gomez-Casati et al. 2005). The potentiation appears to be a result of an increase in the receptors affinity for $\mathrm{ACh}$ as $\mathrm{Ca}^{2+}$ is 


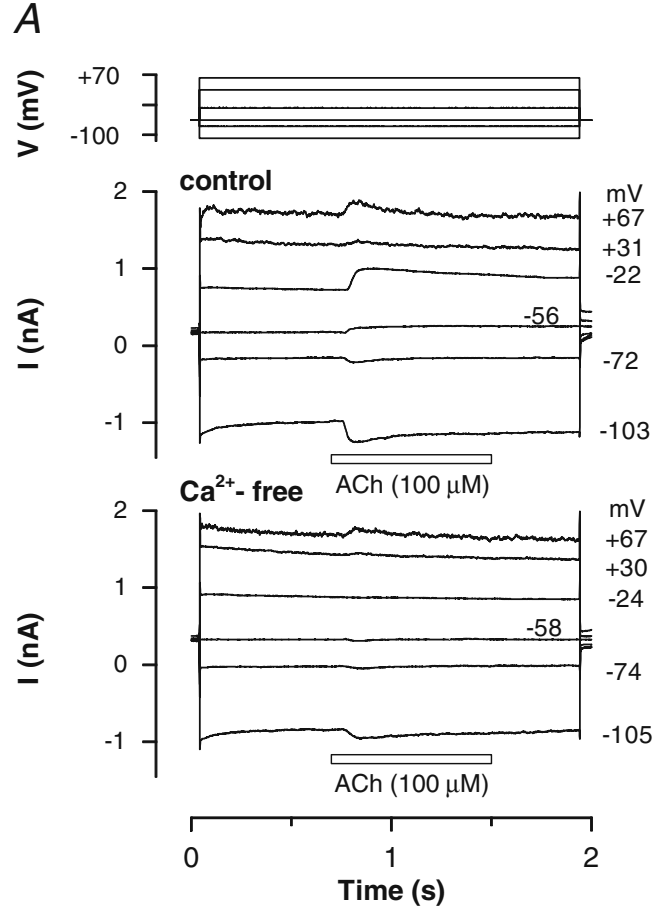

$B$

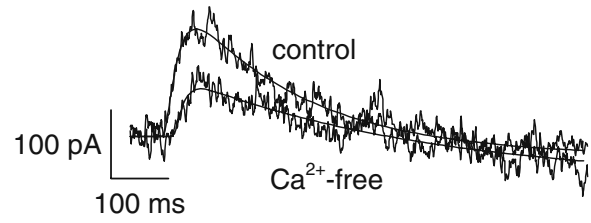

C
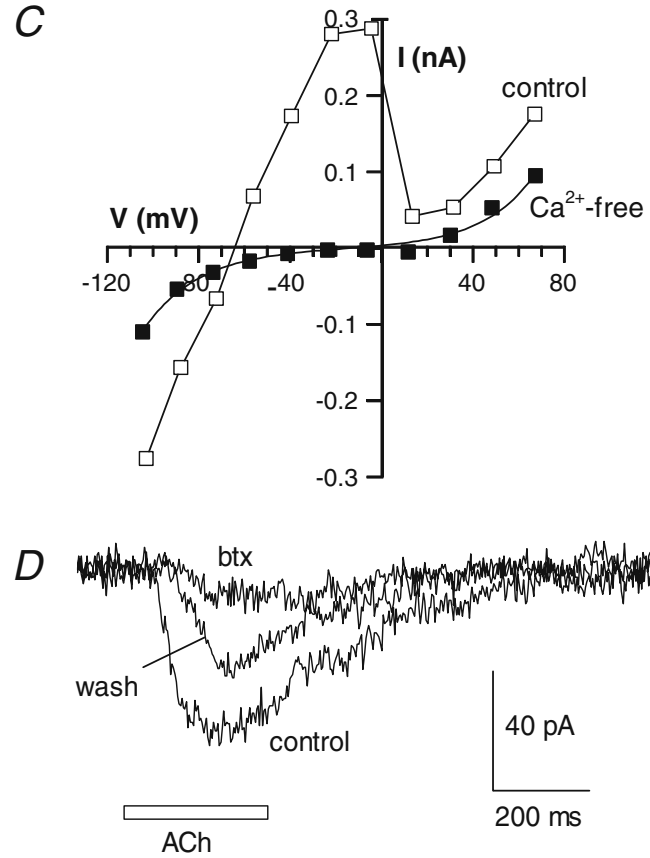

raised $(0-0.5 \mathrm{mM})$, whereas the block occurs at higher concentrations of external $\mathrm{Ca}^{2+}(>0.5 \mathrm{mM})$ as $\mathrm{Ca}^{2+}$ binds reversibly within the channel pore and reduces the flow of monovalent cations through the channel in a voltage-dependent manner, the block
FIG. 1. Response to ACh in the presence and absence of external $\mathrm{Ca}^{2+}$. A Records showing ACh application at different voltages (indicated above) in normal $\mathrm{Ca}^{2+}$ (control, $1.26 \mathrm{mM} \mathrm{Ca}^{2+}$ ) and under nominally $\mathrm{Ca}^{2+}$-free conditions $\left(\mathrm{Ca}^{2+}\right.$-free), with $\mathrm{K}^{+}$-based internal solution (5 mM EGTA). In the control, ACh $(100 \mu \mathrm{M})$ application (indicated by the horizontal bars) induces a response comprising, at negative voltages, an AChR current and a dominant $\mathrm{Ca}^{2+}$-activated $\mathrm{K}^{+}$current (SK2 current). Removal of $\mathrm{Ca}^{2+}$ abolishes the SK2 current leaving the AChR current. The clamp voltage is shown beside the records. B AChR currents recorded at $+67 \mathrm{mV}$ (in A) shown at higher gain. The start of the 800-ms ACh application coincides with the start of the records. Currents have been fitted with Eq. 1. Values obtained for $d, \tau_{1}$ and $\tau_{2}$ were 56, 20 and $214 \mathrm{~ms}$, respectively (control), and 74,14 and $444 \mathrm{~ms}$, respectively $\left(\mathrm{Ca}^{2+}\right.$-free). C $I-V$ curve of peak ACh-sensitive currents shown in A. The control $I-V$ curve is $\mathrm{N}$ shaped $\left(V_{\mathrm{r}}=-65 \mathrm{mV}\right)$, whereas that representing the AChR current, obtained under $\mathrm{Ca}^{2+}$-free conditions, is S-shaped and has been fitted with the single-energy barrier model (Eq. 2). Values obtained for $V_{\mathrm{r}} \gamma$ and $V_{\mathrm{s}}$ were $-14 \mathrm{mV}, 0.48$ and $11.8 \mathrm{mV}$, respectively. D AChR current recorded at $-60 \mathrm{mV}$ from a different $\mathrm{OHC}$. The current was abolished by bath application of $\alpha$-bungarotoxin (btx, $0.2 \mu \mathrm{M}, 2$-min duration). A wash period of 4 min partially restored the response (wash).

being greater at negative voltages. Although we have not investigated either mechanism in detail, our results are consistent with this behaviour. When currents were measured at positive voltages, free of SK2 contamination, the removal of external $\mathrm{Ca}^{2+}$ clearly reduced the size of the AChR current (Fig. 1B). At $+50 \mathrm{mV}$, AChevoked currents were $+88 \pm 14 \mathrm{pA}$ in control compared to $+37 \pm 10 \mathrm{pA}$ in nominally $\mathrm{Ca}^{2+}$-free solution $(n=4)$. This is a more modest effect than previously reported in guinea pig OHCs where a strong reduction in AChR current amplitude $(>80 \%)$ was observed under $\mathrm{Ca}^{2+}$ free conditions (Blanchet et al. 1996). The difference may relate to the external $\mathrm{Mg}^{2+}$ concentration, which was kept constant here but raised in the earlier experiments (Blanchet et al. 1996) since it was used to replace external $\mathrm{Ca}^{2+}$. Magnesium is known to block the $\alpha 9 \alpha 10$ recombinant AChRs and the inner hair cell AChR (Weisstaub et al. 2002; Gomez-Casati et al. 2005).

An effective and reversible block of the AChR is provided by the nicotinic antagonist $\alpha$-bungarotoxin. This was shown to block the biphasic ACh-evoked currents in OHCs (Evans 1996). As expected, a similar block was found for the AChR current recorded after $\mathrm{Ca}^{2+}$ removal (Fig. 1D). The current was reduced to $12-21 \%$ of its peak value during an $\sim 3$-min exposure to $\alpha$-bungarotoxin $(0.2 \mu \mathrm{M})$, and thereafter it recovered back towards control values $(n=3)$.

\section{Isolation of the AChR current by internal} $\mathrm{Cs}^{+}$BAPTA

Once the whole cell recording configuration was established, the $\mathrm{Cs}^{+}$-based internal solution (with $10 \mathrm{mM}$ BAPTA) rapidly dialysed the cell interior and produced a complete block of the $\mathrm{K}^{+}$current. Additionally, the background currents (e.g. voltage- 
sensitive) were greatly reduced by the internal $\mathrm{Cs}^{+}$ which had the advantage of improving the speed and accuracy of the voltage clamp and reducing the background noise (Fig. 2A). BAPTA was also used at $5 \mathrm{mM}$, although at this lower concentration small residual outward SK currents (10-30 pA) were observed in addition to the inward AChR current following ACh application at $-20 \mathrm{mV}( \pm 10 \mathrm{mV})$ in half of the cells tested (three of six cells dialysed with $\mathrm{Cs}^{+}$ internal solution containing $5 \mathrm{mM}$ BAPTA, not shown). The remainder behaved similarly to recordings obtained with the $10 \mathrm{mM}$ BAPTA internal solution, in other words with no contaminating SK2 current apparent in the stated voltage range. Since the presence of any contaminating SK2 current was obvious, we did not employ additional pharmacological block of SK2 channels, for example by apamin, and thus in these experiments (employing internal solutions containing 5 or $10 \mathrm{mM}$ BAPTA), block of the SK2 current was achieved by ensuring adequate intracellular dialysis by the internal solutions.

AChR currents isolated using internal BAPTA were rapidly activating and tended to decline in the continued presence of ACh (Fig. 2A). The currents were fitted with a sigmoidal function incorporating an exponential decay (Eq. 1) as shown (Fig. 2C, D). It should be noted that the kinetics of the recorded
AChR current were limited by the speed of application of ACh and are thus indicative of a fast underlying response (see "Methods"). Typically, with internal Cs-BAPTA (10 mM), the measured activation time constants were 40-60 ms following a delay of 30$60 \mathrm{~ms}$. The decline in the current is presumably due to desensitisation and had a time constant of 100 $400 \mathrm{~ms}$. There were no obvious differences in the kinetics of the response at different voltages.

The $I-V$ relation for the AChR current, constructed by measuring the peak ACh-induced current at each voltage, showed inward and outward rectification (Fig. 1B). The extent of the rectification was greater for outward than for inward currents. The form of the $I-V$ relation lends itself to a single-energy barrier model (Eq. 2) that has been used previously to fit transducer currents in cone photoreceptors and hair cells (Yau and Baylor 1989; Kros et al. 1992; Farris et al. 2004). The model assumes a single blocking site (or energy barrier) within the channel pore and as such is likely to be an oversimplification. Even so, the model provided a good fit to the AChR current $I-V$ curve, and from it the reversal potential $\left(V_{\mathrm{r}}\right)$, the fractional distance of the blocking site through the membrane electric field with respect to the outside $(\gamma)$ and the steepness of the rectification $\left(V_{\mathrm{s}}\right)$ were obtained. For experiments such as that shown in
A
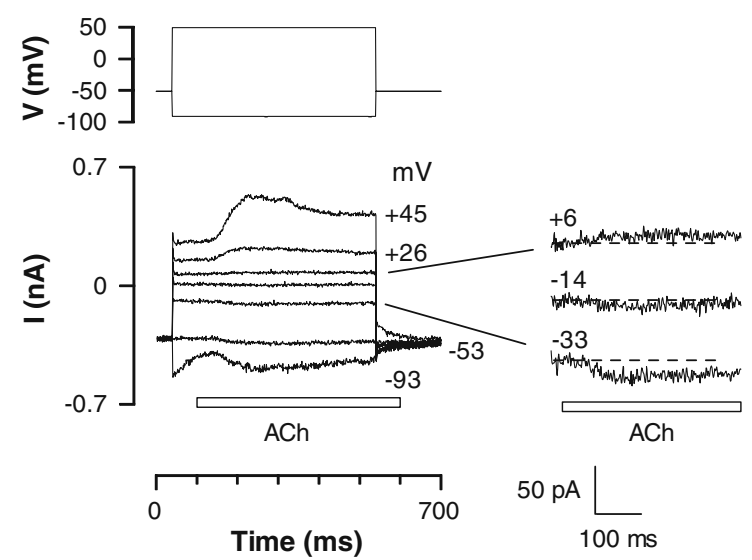

C

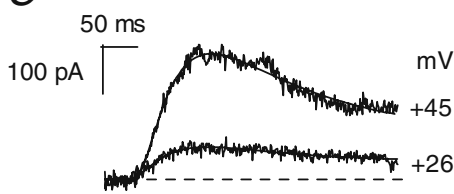

FIG. 2. AChR current recorded in the presence of internal CsBAPTA $(10 \mathrm{mM})$. A Application of ACh $(100 \mu \mathrm{M})$, indicated by the horizontal bar, during voltage clamp steps to different voltages induces a rapidly activating current (AChR current). The small currents seen in either side of the reversal potential have been shown at a higher gain to the right. B $I-V$ curve of the peak AChR currents. The data have been fitted with a simple single-energy barrier model (Eq. 2). Values obtained for $V_{r}, \gamma$ and $V_{s}$ for this cell
B
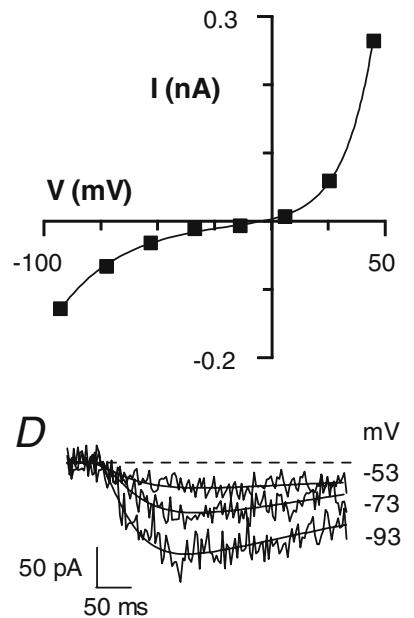

were $-4 \mathrm{mV}, 0.31$ and $8.9 \mathrm{mV}$, respectively. C The AChR currents at positive voltages are fitted with the sigmoidal function (Eq. 1). The start of the records corresponds with the beginning of the ACh application. Values obtained for $d, \tau_{1}$ and $\tau_{2}$ at 29, 54, $313 \mathrm{~ms}$ (-53 mV); $41 \mathrm{~ms}, 46 \mathrm{~ms}, 6.89 \mathrm{~s} \mathrm{(-73} \mathrm{mV);} \mathrm{42,} \mathrm{38,} 827 \mathrm{~ms}$ respectively. D As in C, but for negative voltages; $d, \tau_{1}$ and $\tau_{2}$ were 34,63 and $282 \mathrm{~ms}(-53 \mathrm{mV}) ; 49 \mathrm{~ms}, 37 \mathrm{~ms}$ and $12.5 \mathrm{~s}(-73 \mathrm{mV})$; and 37, 48 and $482 \mathrm{~ms}(-93 \mathrm{mV})$, respectively. 
Figure 2, these parameters $\left(V_{\mathrm{r}}, \gamma\right.$ and $\left.V_{\mathrm{s}}\right)$ were $-4 \pm$ $1 \mathrm{mV}, 0.30 \pm 0.03$ and $11.2 \pm 1.7 \mathrm{mV}$, respectively $(n=4)$. As expected for a cationic conductance, replacement of most of the internal $\mathrm{Cl}$ with methanesulphonate made no significant difference $(3 \pm 3 \mathrm{mV}, 0.28 \pm 0.02$ and $9.8 \pm 1.7 \mathrm{mV}$ were obtained for $V_{\mathrm{r}}, \gamma$ and $V_{\mathrm{s}}$, respectively, $n=3$ ).

The single-energy barrier model assumes that a blocking ion, assumed to be calcium or magnesium as they are known to block both the $\alpha 9 \alpha 10$ receptor and the hair cell AChR channel (Weisstaub et al. 2002; Gomez-Casati et al. 2005), binds to the channel within the pore and produces a voltage-dependent block that is less for larger driving forces and thus gives two-way rectification. This can be understood by the divalent blocking ion being forced off the binding site within the channel by a strong electric field, producing outward rectification at positive voltages (blocking ion forced out of the channel towards the outside) and inward rectification at negative voltages (blocking ion forced towards the inside). The fact that the blocking site (single-energy barrier) is closer to the outside accounts for the greater extent of the outward rectification - of the two possible exit directions, the blocking divalent cation more readily leaves the site towards the outside for an equivalent driving force.

\section{Demonstration of cationic selectivity of the AChR by ionic substitution}

Although there is good evidence that the hair cell AChR is a non-specific cation channel (Fuchs and Murrow 1992; Blanchet et al. 1996; Evans 1996; Dulon and Lenoir 1996), it has yet to be demonstrated that substitution of a permeant cation with a large nonpermeant cation changes the reversal potential. We chose $\mathrm{NMG}^{+}$as an impermeant cation since it does not go through the recombinant $\alpha 9$ and $\alpha 9 \alpha 10$ AChRs (Katz et al. 2000; Weisstaub et al. 2002). An example of AChR currents recorded with the $\mathrm{NMG}^{+}$internal solution is shown in Figure 3. From the single-energy barrier fit to the $I-V$ relation (Fig. 3B), the parameters $V_{\mathrm{r}}, \gamma$ and $V_{\mathrm{s}}$ were $+9 \pm 2 \mathrm{mV}, 0.37 \pm 0.01$ and $11.8 \pm 1.8 \mathrm{mV}$, respectively $(n=3)$. Thus, the main effect of replacing most of the internal $\mathrm{Cs}^{+}$with $\mathrm{NMG}^{+}$was a shift of $+13 \mathrm{mV}$ in the reversal potential (from -4 to $+9 \mathrm{mV}$ ). This shift is in the direction expected for a cation channel that was more permeable to small monovalent cations than to $\mathrm{NMG}^{+}$.

From the reversal potential measurements, we have estimated the relative permeability of $\mathrm{Ca}^{2+}$ to other small monovalent cations through the AChR channel using Eq. 3 (see "Methods"). We have assumed that the channel's permeability to small monovalent cations is equal $\left(P_{\mathrm{Cs}}=P_{\mathrm{K}}=P_{\mathrm{Na}}\right)$ and, for simplicity, have ignored the contribution of $\mathrm{Mg}^{2+}$ (held constant between control and test solutions). Based on the reversal potentials measured above $\left(V_{\mathrm{r}}=-4 \mathrm{mV}\right.$ in control and $+9 \mathrm{mV}$ with internal $\mathrm{NMG}^{+}$), values for $P_{\mathrm{Ca}} / P_{\mathrm{K}}$ and $P_{\mathrm{NMG}} / P_{\mathrm{K}}$ were calculated as 5.4 and 0.42 , respectively $\left(P_{\mathrm{Ca}} / P_{\mathrm{K}}\right.$ initially calculated for $V_{\mathrm{r}}=-4 \mathrm{mV}$ and then kept constant for the calculation of $P_{\mathrm{NMG}} /$ $P_{\mathrm{K}}$ using $\left.V_{\mathrm{r}}=+9 \mathrm{mV}\right)$. Note that in the case of zero permeability to $\mathrm{NMG}^{+}, V_{\mathrm{r}}$ was calculated as $+25 \mathrm{mV}$ (Eq. 3). Thus, these calculations, based on $V_{\mathrm{r}}$ measurements and with the stated underlying assumptions, indicate that the AChR channel has a high permeability to $\mathrm{Ca}^{2+}$ and a low (but finite) permeability to $\mathrm{NMG}^{+}$, relative to small monovalent cations like $\mathrm{K}^{+}$and $\mathrm{Cs}^{+}$. Although the permeability of the AChR channel to $\mathrm{NMG}^{+}$is higher than expected for a large cation that might be expected to be largely impermeant, the data do demonstrate the cationic selectivity of the AChR channel.

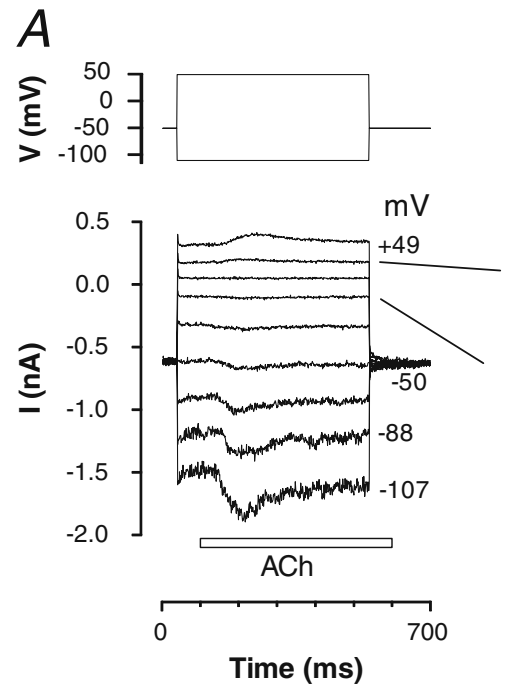

$B$

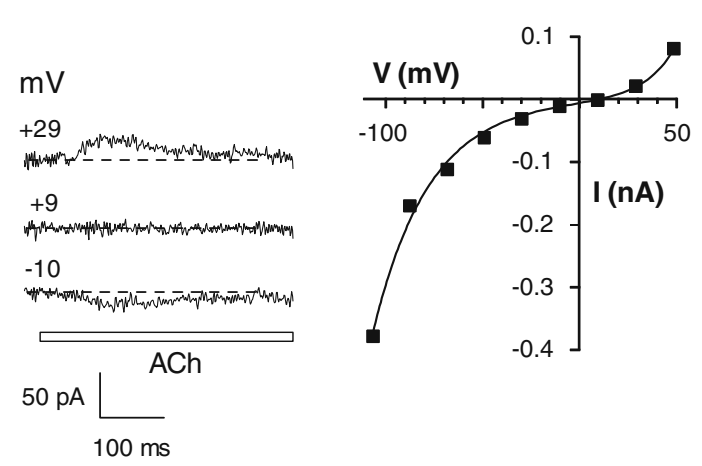

FIG. 3. Change in reversal potential with low internal $\mathrm{Cs}^{+}\left(\mathrm{NMG}^{+}\right)$. A Family of AChR currents recorded with the internal $\mathrm{Cs}^{+}\left(\mathrm{NMG}^{+}\right)$solution at different voltages as indicated. Timing of the voltage steps and ACh $(100 \mu \mathrm{M})$ applications is indicated above and below, respectively. Records close to the reversal potential are shown at higher gain on the right. B $I-V$ curve of the peak AChR currents. Data fitted with Eq. 2. $V_{\mathrm{r}}, \gamma$ and $V_{\mathrm{s}}$ : $+9 \mathrm{mV}, 0.35$ and $10.1 \mathrm{mV}$, respectively. The positive shift in reversal potential (compare with Fig. 2B) indicates that channel is permeable to small cations but less so to the much larger cation $\left(\mathrm{NMG}^{+}\right)$. Internal solution was $\mathrm{NMG}^{+}$-based with 10 mM BAPTA. 
FIG. 4. Exposure to low $\mathrm{Ca}^{2+}$ produces a potentiated $\mathrm{ACh}$ response. A Currents recorded (bottom) in response to a series of voltage clamp steps (top) in control $\left(1.26 \mathrm{mM} \mathrm{Ca}^{2+}\right)$ and in $0.4 \mathrm{mM} \mathrm{Ca}^{2+} / 0 \mathrm{mMMg}^{2+}$ $\left(0.4 \mathrm{mM} \mathrm{Ca}^{2+}\right)$ as indicated. ACh $(100 \mu \mathrm{M})$ applied as indicated by the horizontal bars. B AChR currents shown at $+50 \mathrm{mV}$ under both conditions. Values for $\mathrm{V}_{\mathrm{r}}, \mathrm{y}$ and $\mathrm{V}_{\mathrm{s}}$ were $-2.3 \mathrm{mV}, 0.34,10.3 \mathrm{mV}$ (control) and $-6.2 \mathrm{mV}, 0.42,10.6 \mathrm{mV}\left(0.4 \mathrm{Ca}^{2+} / 0 \mathrm{mM} \mathrm{Mg}^{2+}\right)$. The current in the low $\mathrm{Ca}^{2+}$ solution is larger (potentiated). The ACh application onset is indicated by the dashed vertical line. C $I-V$ curves for the peak AChR currents under both conditions. The currents in the low $\mathrm{Ca}^{2+}$ solution $\left(0 \mathrm{mM} \mathrm{Mg}^{2+}\right)$ are larger, especially at negative voltages, indicating a potentiated response. In this experiment, a single-barrelled puffer pipette was used, initially with $\mathrm{ACh}$ in $0.4 \mathrm{mM} \mathrm{Ca}^{2+} / 0 \mathrm{mM} \mathrm{Mg}^{2+}$ solution, which was then changed to one containing $\mathrm{ACh}$ in the control solution during the bath

We attempted to extend this result by placing $\mathrm{NMG}^{+}$in the external solution $(30 \mathrm{mM} \mathrm{Na} / 111 \mathrm{mM}$ $\mathrm{NMG}^{+}$) and assessing the shift in the reversal potential, which would be expected to be in the opposite (negative) direction. Under these conditions, however, the AChR current was reversibly reduced in a voltage-dependent manner, the effect being greatest at negative voltages (not shown). In the presence of external $\mathrm{NMG}^{+}$, the only reproducible and measurable AChR currents occurred at $+50 \mathrm{mV}(+27 \pm 14 \mathrm{pA}$ compared to $+91 \pm 44 \mathrm{pA}$ in control, $n=3)$. At other voltages, they were either 0 or $<10 \mathrm{pA}$, which precluded any measurement of the reversal potential. The reduction in external $\mathrm{Na}^{+}$would be expected to reduce inward currents through the AChR when replaced by a larger, less permeant cation such as $\mathrm{NMG}^{+}$; however, there was also a pronounced reduction in outward current. This voltage-dependent effect might indicate that $\mathrm{NMG}^{+}$blocks the channel from the outside (internal $\mathrm{NMG}^{+}$had no obvious effect on AChR currents aside from the change in the reversal potential), but further experiments are needed to explore the efficacy and mechanism of this apparent block.

\section{Potentiation of the AChR current by external $\mathrm{Ca}^{+}$}

To look for a $\mathrm{Ca}^{2+}$-dependent potentiation of the AChR current in $\mathrm{OHCs}$, we exposed cells to a low $\mathrm{Ca}^{2+}$ solution without $\mathrm{Mg}^{2+}\left(0.4 \mathrm{mM} \mathrm{Ca}^{2+} / 0 \mathrm{Mg}^{2+}\right)$. These conditions are close to those that provide maximum potentiation of the AChR current in neonatal inner hair cells $(0.5 \mathrm{mM}$ $\mathrm{Ca}^{2+} / 0 \mathrm{Mg}^{2+}$; Gomez-Casati et al. 2005). In these experiments, the $\mathrm{K}^{+}$-based internal solution with $5 \mathrm{mM}$ BAPTA was used to eliminate the SK2 current. Figure 4A shows an example of AChR currents under both control $\left(1.26 \mathrm{mM} \mathrm{Ca}^{2+} / 0.9 \mathrm{mM} \mathrm{Mg}^{2+}\right)$ and test conditions. The AChR currents were larger in the $0.4 \mathrm{mM} \mathrm{Ca}^{2+} / 0 \mathrm{Mg}^{2+}$ solution, particularly at negative voltages (Fig. 4A, C). AChR currents recorded at $+50 \mathrm{mV}$ (for comparison with Fig. 1B) are shown superimposed (Fig. 4B) and the
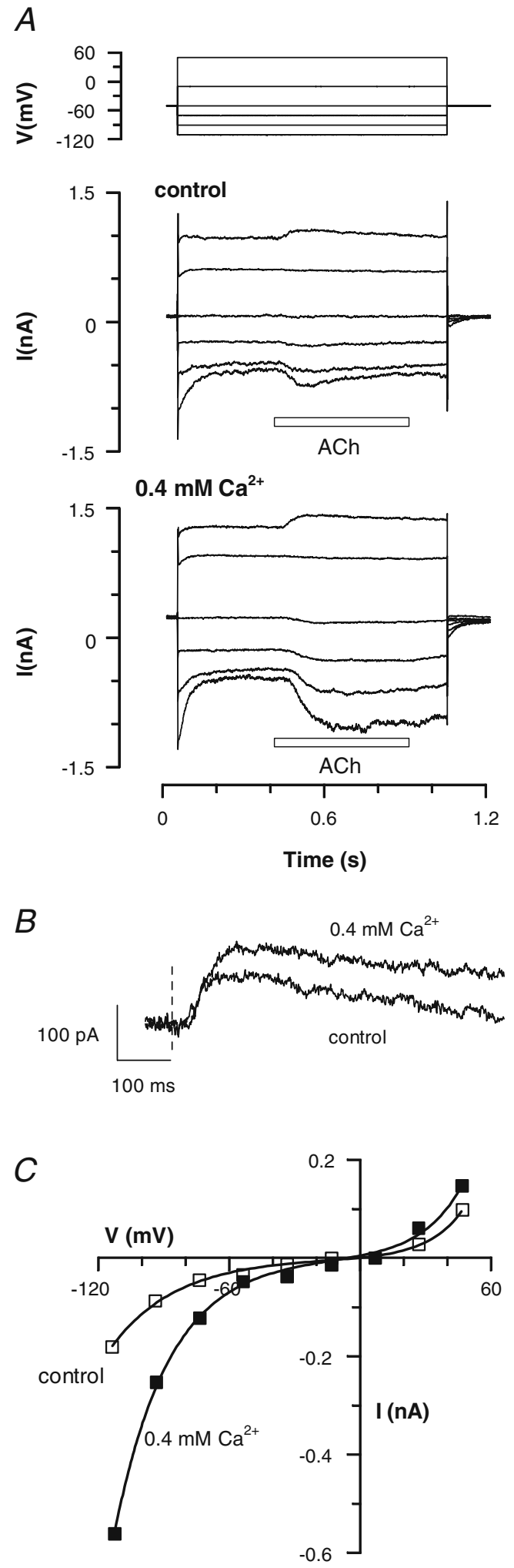

potentiation in the low divalent solution is apparent. The small increase in current at $+50 \mathrm{mV}$ was not significant overall; however, if the comparison was made at $-70 \mathrm{mV}$, where the divergence of the $I-V$ curves is greater (Fig. 4C), the difference was significant $(-51 \pm$ 
$10 \mathrm{pA}$ (control), $-128 \pm 6 \mathrm{pA}\left(0.4 \mathrm{mM} \mathrm{Ca}^{2+} / 0 \mathrm{Mg}^{2+}\right), p<$ $0.02, n=4)$. The single-energy barrier fits to the $I-V$ data (Fig. $4 \mathrm{C}$ ) revealed a small negative shift $(-2.7 \mathrm{mV})$ in the mean reversal potential between control and $0.4 \mathrm{mM}$ $\mathrm{Ca}^{2+} / 0 \mathrm{Mg}^{2+}$ solution $(n=4)$. This compares with a calculated shift of $-1.5 \mathrm{mV}$ (Eq. 3 with $P_{\mathrm{K}}=\mathrm{P}_{\mathrm{Cs}}=\mathrm{P}_{\mathrm{Na}}$; $\left.P_{\mathrm{Ca}} / P_{\mathrm{K}}=5.4\right)$. Given the assumptions made, these values are reasonably close. There also appeared to be a small shift in $\gamma$, essentially the location of the blocking site within the channel, which was $0.33 \pm 0.03$ (control) and $0.44 \pm 0.02\left(0.4 \mathrm{mM} \mathrm{Ca}^{2+} / 0 \mathrm{Mg}^{2+}\right)$.

Since $\mathrm{Mg}^{2+}$ is a known blocker of both the $\alpha 9 \alpha 10$ receptor and the IHC AChR, we investigated the effects of $\mathrm{Mg}^{2+}$ removal on AChR currents (Weisstaub et al. 2002; Gomez-Casati et al. 2005). Cells were dialysed with the $5 \mathrm{mM}$ BAPTA internal $\mathrm{K}^{+}$-based solution and measurements were made on different cells at $-50 \mathrm{mV}$. The control AChR current was $-11 \pm$ $1 \mathrm{pA}(n=6)$, and in nominally $\mathrm{Mg}^{2+}$-free solution, the AChR current was $-13 \pm 3 \mathrm{pA}(n=4)$. This rather modest affect on the AChR current would suggest that the potentiated current demonstrated in the $0.4 \mathrm{mM} \mathrm{Ca} \mathrm{Ca}^{2+} / 0 \mathrm{Mg}^{2+}$ solution is principally a $\mathrm{Ca}^{2+}$ effect.

\section{Block of the AChR current by high external $\mathrm{Ca}^{2+}$}

When OHCs were bathed in normal $\mathrm{Ca}^{2+}(1 \mathrm{mM})$, application of $\mathrm{ACh}$ in a solution with high $\mathrm{Ca}^{2+}$ $(10 \mathrm{mM})$ produced a much smaller response $(18 \%$ of control at $+50 \mathrm{mV}$ ) compared to controls (Fig. $5 \mathrm{~A}$, B), suggestive of a blocking effect of external $\mathrm{Ca}^{2+}$. The reduction in the presence of high $\mathrm{Ca}^{2+}$ was completely reversible following these brief applica- tions. Repeating the experiment with high $\mathrm{Ca}^{2+}$ (10 or $45 \mathrm{mM}$ ) in the bath gave an apparently complete block at $+50 \mathrm{mV}$, although increased cell conductance and noise in the recordings made measurements problematic at this voltage. At $-70 \mathrm{mV}$, where there was much less change in conductance, AChR currents in normal and high $\mathrm{Ca}^{2+}$ were $-116 \pm 57$ and $-20 \pm$ $15 \mathrm{pA}$, respectively $(n=3)$. These experiments are consistent with a rapid block of the AChR by high external $\mathrm{Ca}^{2+}$.

The reversal potential in the $10 \mathrm{mM}$ Ca solution was $+4 \mathrm{mV}$, although the small size of the currents limits the accuracy of this measurement (Fig. 5B). Using the previously calculated relative $\mathrm{Ca}^{2+}$ permeability $\left(P_{\mathrm{Ca}} / P_{\mathrm{K}}=5.4\right)$, a reversal potential of $+8.5 \mathrm{mV}$ was calculated in $10 \mathrm{mM} \mathrm{Ca}^{2+}$ (Eq. 3). The difference might suggest that the value used is an overestimate; however, in view of concerns regarding the accuracy of the $V_{\mathrm{r}}$ measurement in high $\mathrm{Ca}^{2+}$, it seems safest to conclude that the $P_{\mathrm{Ca}} / P_{\mathrm{K}}$ of the $\mathrm{AChR}$ channel in OHCs is $\sim 5$.

\section{DISCUSSION}

AChR conductance and the blocking site

These experiments show that the OHC AChR is a cation channel that has a distinctive $I-V$ relation showing bidirectional rectification with a particularly prominent outward component in normal $(1 \mathrm{mM})$ external $\mathrm{Ca}^{2+}$. The bidirectional rectification has been previously found in OHCs (Blanchet et al. 1996; Dulon and Lenoir 1996); however, we have extended the voltage range and shown that the $I-V$ relation
A

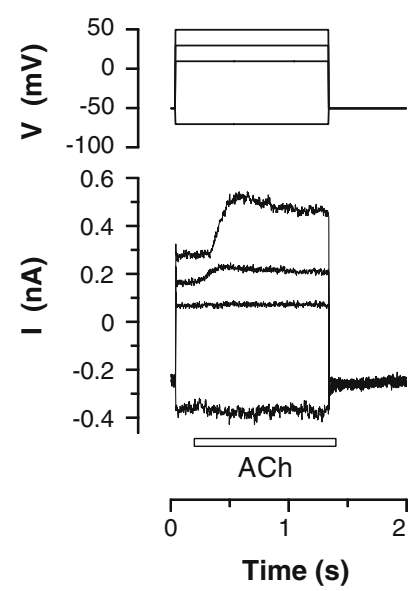

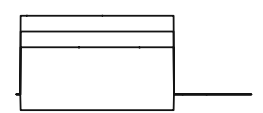
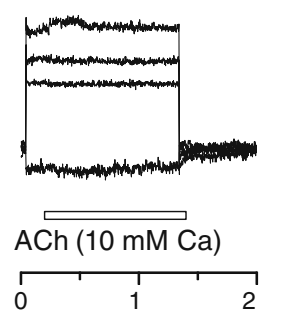

Time (s)

FIG. 5. High external $\mathrm{Ca}^{2+}$ blocks the $\mathrm{AChR}$ current. A Currents recorded in response to $\mathrm{ACh}(100 \mu \mathrm{M})$ at different voltages (top). The $\mathrm{OHC}$ was bathed in normal $(1 \mathrm{mM}) \mathrm{Ca}^{2+}$ and $\mathrm{ACh}$ was applied either in the bath solution or in a solution containing $10 \mathrm{mM} \mathrm{Ca}^{2+}$, as indicated below the records (horizontal bars indicate timing of

B
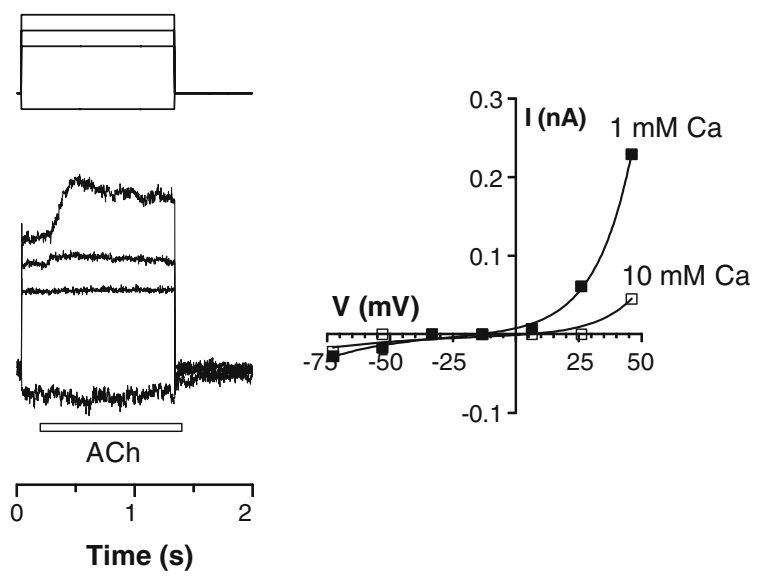

application). B I-V curve of the peak AChR current in the normal and $10 \mathrm{mM}$ external $\mathrm{Ca}^{2+}$ solutions. The data have been fitted with the single-energy barrier model with the following values for $V_{\mathrm{r}} \gamma$ and $V_{\mathrm{s}}$ : $-15 \mathrm{mV}, 0.35,9.6 \mathrm{mV}$ (control) and $+4 \mathrm{mV}, 0.26,10.6 \mathrm{mV}$ $\left(10 \mathrm{mM} \mathrm{Ca}^{2+}\right)$. Internal solution was $\mathrm{Cs}^{+}$-based with $10 \mathrm{mM}$ BAPTA. 
under a variety of experimental conditions accords with a single-energy barrier model. As expected for a nicotinic receptor, the currents activate rapidly and are blocked by $\alpha$-bungarotoxin. The development of a faster application method is likely to result in larger AChR currents showing faster desensitisation (and faster activation). To date, the fastest postsynaptic effects in hair cells have been observed in response to spontaneous (usually in elevated external $\mathrm{K}^{+}$) or electrically evoked quantal release of ACh from efferent terminals onto neonatal IHCs (e.g. Katz et al. 2004; Goutman et al. 2005) or OHCs (Oliver et al. 2000; Lioudyno et al. 2004). Typical values for the rise time and decay time constants (for the miniature AChR currents) are 9 and $20 \mathrm{~ms}$, respectively. Addition of the SK current slows down the decay to $40-50 \mathrm{~ms}$, indicating that this current principally determines the decay time and therefore is the ratelimiting step for the postsynaptic conductance change (Chan and Evans 1998; Oliver et al. 2000; Katz et al. 2004).

The single-energy barrier model gave a good fit to the $I-V$ data points in all conditions where AChR currents could be measured reliably around the reversal potential (e.g. control, $0.4 \mathrm{mM} \mathrm{Ca}^{2+}$, low internal $\left.\mathrm{Cs}^{+}\left(\mathrm{NMG}^{+}\right)\right)$. Using this model, we found an energy barrier or blocking site about 0.30 of the way through the channel from the outside. In low $\mathrm{Ca}^{2+}$ solutions, this value was slightly higher $(0.44)$. This indicates an apparent shift in the single-energy barrier towards the channel centre in the partial absence of divalent cations, but at present, the significance of this is unclear. Although we did not investigate in detail the nature of the block, our data suggest that $\mathrm{Ca}^{2+}$ can block the channel from the outside. In the presence of normal external $\mathrm{Ca}^{2+}$, the prominent outward rectification is suggestive of $\mathrm{Ca}^{2+}$ entering and blocking from the outside and being more readily expelled from its binding site towards the outside (as the membrane potential becomes more positive) than towards the inside (as the membrane potential becomes more negative). This behaviour has been also shown for recombinant $\alpha 9 \alpha 10$ AChRs (Weisstaub et al. 2002). In the nominal absence of external $\mathrm{Ca}^{2+}$, the more symmetrical $I-V$ relation (approximately equal outward and inward components, see Fig. 1C) might reflect the lifting of the $\mathrm{Ca}^{2+}$ block, although the blocking effects of $\mathrm{Ca}^{2+}$ at low concentrations $(<1 \mathrm{mM})$, where potentiation occurs, are unknown. Presumably under these conditions, $\mathrm{Mg}^{2+}$ would exert some block via the same site, but resolution of this issue would require further experiments on the effects of $\mathrm{Mg}^{2+}$ on the $I-V$ characteristics of the AChR. The potentiation appears to be due to an allosteric modulation of AChR gating by $\mathrm{Ca}^{2+}$, and it has been described in several neuronal nicotinic AChRs as well as in neonatal IHCs and in the recombinant $\alpha 9 \alpha 10$ nicotinic receptor (Mulle et al. 1992; Gomez-Casati et al. 2005; Weisstaub et al. 2002).

\section{The AChR in $\mathrm{OHCs}$}

The results are consistent with an OHC AChR that is very similar to the recombinant $\alpha 9 \alpha 10$ nicotinic receptor. The two nicotinic receptors are very close in terms of the reversal potential and the bidirectional rectification, and they are both cation channels with a high $\mathrm{Ca}^{2+}$ permeability (although estimates differ) and a similar pharmacology (e.g. reversible block by nicotinic antagonists such as curare and $\alpha$-bungarotoxin). Also, although our data are more limited, we have shown that the OHC AChR (like the $\alpha 9 \alpha 10$ receptor) shows potentiation in the $0.4 \mathrm{mM} \mathrm{Ca} \mathrm{Ca}^{2+} / 0 \mathrm{Mg}^{2+}$ solution and is blocked by high external $\mathrm{Ca}^{2+}$. In contrast, the OHC results are not consistent with a $\alpha 9$ homomeric AChR since recombinant $\alpha 9$ receptors show only outward rectification, $\mathrm{Ca}^{2+}$ block (not potentiation), and they do not desensitise in the continued presence of ACh (Katz et al. 2000). The transiently expressed AChR in neonatal IHCs also has a very close similarity to the recombinant $\alpha 9 \alpha 10$ receptor, suggesting that the hair cell AChR is composed of both the $\alpha 9$ and $\alpha 10$ subunits (Gomez-Casati et al. 2005). The best estimates to date of the $\mathrm{Ca}^{2+}$ permeability of the $\alpha 9 \alpha 10 \mathrm{AChR}$ and the IHC AChR suggest that they are approximately eight to ten times more permeable to $\mathrm{Ca}^{2+}$ than to $\mathrm{Na}^{+}$(Weisstaub et al. 2002; Gomez-Casati et al. 2005). The value reported here $(\sim 5)$ is smaller and might reflect the limitations of the present study where it has not been possible to assess reversal potentials under conditions where $\mathrm{Ca}^{2+}$ ions are the main charge carriers. It is worth noting that the shift in $V_{\mathrm{r}}(+15 \mathrm{mV})$ when external $\mathrm{Ca}^{2+}$ was raised from 0.5 to $10 \mathrm{mM}$ ( -9 to $+6 \mathrm{mV}$ ) in IHCs (Gomez-Casati et al. 2005) is about double that reported here $\left(-3 \mathrm{mV}\right.$ in $0.4 \mathrm{mM} \mathrm{Ca}^{2+}$ to $+4 \mathrm{mV}$ in $\left.10 \mathrm{mM} \mathrm{Ca}^{2+}\right)$, in agreement with the respective estimates of $\mathrm{Ca}^{2+}$ permeability.

The apparent block of the OHC AChR by external $\mathrm{NMG}^{+}$was an unexpected finding, although a similar block of AChRs has been previously reported in retinal ganglion cells (Yazejian and Fain 1993). $\mathrm{NMG}^{+}$is often used as an impermeant cation in reversal potential studies, as it was in the recombinant $\alpha 9 \alpha 10$ receptor study (Weisstaub et al. 2002). These authors showed that in $\mathrm{Na}^{+}$-based external solutions, external $\mathrm{Ca}^{2+}(>0.5 \mathrm{mM})$ blocked inward $\mathrm{Na}^{+}$current through the $\alpha 9 \alpha 10$ receptor channel; however, with $\mathrm{NMG}^{+}$-based solutions (with divalent cations as the only charge carriers), at least at the low end $(<4 \mathrm{mM}$ $\mathrm{Ca}^{2+}$ or $\left.\mathrm{Ba}^{2+}\right)$, inward currents increased almost 
linearly with divalent concentration. Furthermore, the outward currents appeared unaffected by the presence of external $\mathrm{NMG}^{+}$. This contrasts with the situation in OHCs where AChR currents showed a voltage-sensitive reduction in amplitude, especially at negative voltages, indicative of a channel block by external $\mathrm{NMG}^{+}$. At present, we cannot account for this difference, and more experiments are needed to understand its significance.

\section{The AChR and efferent inhibition of $\mathrm{OHCs}$}

The role of the AChR in OHCs is to provide efferent inhibition, probably via the ensuing hyperpolarisation of the OHC. The open AChR produces hyperpolarisation by allowing calcium into the cell, thereby activating the calcium-dependent potassium current, which as the dominant current ensures a hyperpolarising response. Thus, the receptor's high-calcium permeability is central to its physiological role. The single-energy barrier model we have used to fit the $I-$ $V$ data assumes a blocking site within the channel, and as suggested above, the most likely occupant of this site is calcium or magnesium. Since the receptor is both permeable to, and blocked by, calcium, it is reasonable to call $\mathrm{Ca}^{2+}$ a permeant blocker of the AChR channel. The same cannot be said of $\mathrm{Mg}^{2+}$ since its permeability through the OHC AChR is unknown at present. Most likely, the block of the channel reduces the inward $\mathrm{Na}^{+}$current and the resultant depolarisation whilst still allowing $\mathrm{Ca}^{2+}$ entry (Weisstaub et al. 2002; Gomez-Casati et al. 2005). The notion of an excitatory receptor underlying an inhibitory response, which at first glance might seem unusual, in fact provides an efficient inhibitory mechanism. The high $\mathrm{Ca}^{2+}$ permeability of the open AChR channel ensures a powerful inhibition as $\mathrm{Ca}^{2+}$ rises in the cell, and subsequent $\mathrm{Ca}^{2+}$. induced $\mathrm{Ca}^{2+}$ release from intracellular stores appears to amplify the inhibitory response. The downside of this process relates to the cell homeostasis since presumably metabolic energy must be used to restore the intracellular $\mathrm{Ca}^{2+}$ concentration following a burst of efferent activity. Recent results suggest that OHCs have a high concentration of diffusible $\mathrm{Ca}^{2+}$ buffer (Hackney et al. 2005), and this would be advantageous given the potentially high $\mathrm{Ca}^{2+}$ load on the cell.

\section{ACKNOWLEDGEMENTS}

Supported by the Wellcome Trust (046090). We thank Dr Mary Palmer for comments on the paper, Prof. Corné Kros for suggesting the single-energy barrier model and Prof. John Chapman for advice on the equations.

\section{REFERENCES}

Art JJ, Fettiplace R, Fuchs PA (1984) Synaptic hyperpolarization and inhibition of turtle cochlear hair cells. J Physiol 356:525-550

Blanchet C, Erostegui C, Sugasawa M, Dulon D (1996) Acetylcholineinduced potassium current of guinea pig outer hair cells: its dependence on a calcium influx through nicotinic-like receptors. J Neurosci 16(8):2574-2584

Brown MC, NutTall AL (1984) Efferent control of cochlear inner hair cell responses in the guinea-pig. J Physiol 354:625-646

Chan E, Evans MG (1998) Kinetics of activation of $\mathrm{a} \mathrm{Ca}^{2+}$-dependent $\mathrm{K}^{+}$current induced by flash photolysis of caged carbachol in isolated guinea-pig outer hair cells. Neurosci Lett 254:45-48

Dulon D, LenoIR M (1996) Cholinergic responses in developing outer hair cells of the rat cochlea. Eur J Neurosci 8(9):19451952

Dulon D, Luo L, Zhang C, Ryan AF (1998) Expression of smallconductance calcium-activated potassium channels (SK) in outer hair cells of the rat cochlea. Eur J Neurosci 10:907-915

Elgoyhen A, Vetter D, Katz E, Rothlin C, Heinemann S, Boulter J (2001) Alpha 10: a determinant of nicotinic cholinergic receptor function in mammalian vestibular and cochlear mechanosensory hair cells. P Natl Acad Sci USA 98(6):3501-3506

Evans MG (1996) Acetylcholine activates two currents in guinea-pig outer hair cells. J Physiol 491(2):563-578

Evans MG, Lagostena L, Darbon P, Mammano F (2000) Cholinergic control of membrane conductance and intracellular free $\mathrm{Ca}^{2+}$ in outer hair cells of the guinea pig cochlea. Cell Calcium 28 (3):195-203

Farris HE, LeBlanc CL, Goswami J, Ricci AJ (2004) Probing the pore of the auditory hair cell mechanotransducer channel in turtle. J Physiol 558:769-792

Fuchs PA, Murrow BW (1992) Cholinergic inhibition of short (outer) hair cells of the chicks cochlea. J Neurosci 12(3):800-809

Glowatzki E, Fuchs PA (2000) Cholinergic synaptic inhibition of inner hair cells in the neonatal mammalian cochlea. Science 288:2366-2368

Gomez-Casati ME, Fuchs PA, Elgoyhen AB, Katz E (2005) Biophysical and pharmacological characterization of nicotinic cholinergic receptors in rat cochlear inner hair cells. J Physiol 566:103-118

Goutman JD, Fuchs PA, Glowatzki E (2005) Facilitating efferent inhibition of inner hair cells in the cochlea of the neonatal rat. J Physiol 566:49-59

Hackney CM, Mahendrasingam S, Penn A, Fettiplace R (2005) The concentrations of calcium buffering proteins in mammalian cochlear hair cells. J Neurosci 25:7867-7875

Housley GD, Ashmore JF (1992) Ionic currents of outer hair cells isolated from the guinea-pig cochlea. J Physiol 448:73-98

Jack JJB, Noble D, Tsien RW (1975) Electric current flow in excitable cells. Oxford University Press, Oxford

Katz E, Verbitsky M, Rothlin CV, Vetter DE, Heinemann SF, ElgoYhen AB (2000) High calcium permeability and calcium block of the alpha9 nicotinic acetylcholine receptor. Hear Res 141:117-128

Katz E, Elgoyhen AB, Gomez-Casati ME, Knipper M, Vetter DE, Fuchs PA, GLOWATZKI E (2004) Developmental regulation of nicotinic synapses on cochlear inner hair cells. J Neurosci 24:7814-7820

Kennedy HJ, Crawford AC, Fettiplace R (2005) Force generation by mammalian hair bundles supports a role in cochlear amplification. Nature 433:880-883

Kros CI, Rusch A, RichARDSON GP (1992) Mechano-electrical transducer currents in hair cells of the cultured neonatal mouse cochlea. Proc R Soc Lond B 249:185-193

Liberman MC, Gao J, He DZ, Wu X, Jia S, Zuo J (2002) Prestin is required for electromotility of the outer hair cell and for the cochlear amplifier. Nature 419:300-304 
Lioudyno M, Hiel H, Kong JH, Katz E, Waldman E, ParameshwaranIYer S, GlowatzKi E, Fuchs PA (2004) A 'synaptoplasmic cistern' mediates rapid inhibition of cochlear hair cells. J Neurosci 24:11160-11164

Mayer M, Westbrook G (1987) Permeation and block of N-methyl-Daspartic acid receptor channels by divalent cations in mouse cultured central neurones. J Physiol 394:501-527

McNiven AI, Yuhas WA, Fuchs PA (1996) Ionic dependence and agonist preference of an acetylcholine receptor in hair cells. Audit Neurosci 2(1):63-77

Mulle C, Lena C, Changeux JP (1992) Potentiation of nicotinic receptor response by external calcium in rat central neurons. Neuron 8:937-945

Oliver D, Klocker N, Schuck J, Baukrowitz T, Ruppersberg JP, Fakler B (2000) Gating of $\mathrm{Ca}^{2+}$-activated $\mathrm{K}^{+}$channels controls fast inhibitory synaptic transmission at auditory outer hair cells. Neuron 26:595-601
Weisstaub N, Vetter DE, Elgoyhen AB, Katz E (2002) The $\alpha 9 \alpha 10$ nicotinic acetylcholine receptor is permeable to and is modulated by divalent cations. Hear Res 167:122-135

Wiederhold ML, Kiang NYS (1970) Effects of electric stimulation of the crossed olivocochlear bundle on single auditory-nerve fibers in the cat. J Acoust Soc Am 48:950-965

YAU K-W, BAYLOR DA (1989) Cyclic GMP-activated conductance of retinal photoreceptor cells. A Rev Neurosci 12:289-327

YazeJIAN B, FaIn GL (1993) Whole-cell currents activated at nicotinic acetylcholine-receptors on ganglion-cells isolated from goldfish retina. Visual Neurosci 10:353-361

Yuhas WA, Fuchs PA (1999) Apamin-sensitive, small-conductance, calcium-activated potassium channels mediate cholinergic inhibition of chick auditory hair cells. J Comp Physiol A 185:455-462

Zheng J, Shen W, He DZ, Long KB, Madison LD, Dallos P (2000) Prestin is the motor protein of cochlear outer hair cells. Nature 405:149-155 